\title{
The Formation for Citizenship in the School and Civic Participation of Students, Important Factors of Active Citizenship
}

\author{
Msc. Lindita Lutaj \\ University "Alexander Moisiu" Durrës, Faculty of Education; Department of Pedagogy \\ Email-I.lutaj @ yahoo.com
}

Doi:10.5901/mjss.2014.v5n2p609

\begin{abstract}
Reforms in the field of civic education aim to bring qualitative and steady changes in order to include this change in its breadth and depth. Civic education is not only to teach you how to be good citizens now, but also how to practice our citizenship, and be better citizens in the future. In a democracy, civic participation is seen as an indicator of democracy. The higher the civic participation is the more mature democratic standards are. This study is intended to help readers assess the contribution of school in the Education of students with Democratic Citizenship, and to prepare them to assume the role of active citizens in democracy. Civic education requires a range of skills and practices, which young people should develop through their engagement in civil society and in civic actions. It is important to be understood by all: the big role of school in the preparation of active and responsible citizens, how present is the spirit of active citizenship in school, how educated are the students with the skills and habits of a collaborative work as active citizens of a democratic society. Also should be seen to what level is their motivation for justice, solidarity, change of reality, to take part in activities that require extensive civic participation, to create friendly relations, to share common interests, to be informed, to take initiatives in organizing various activities. Teachers should bring novelties in their work, because students whose voice is heard in school, whose opinion is respected, and know how to recognize and respect the rights and responsibilities, are more prepared as active citizens in the future.
\end{abstract}

Keywords: Active citizenship, participation, community, curricula, civic education.

\section{Introduction}

In Article 12.2 of the "Law on Pre-university Educational system" says: "The public school community, composed of students, teachers, all the other school staff, parents and other social partners, aims the raising of learning - educational level of students and their optimum integration into life, emancipation and progress of the country. ("Law on Preuniversity Educational system" 1995 p.7). Therefore it is the duty of the school to prepare students for active involvement in all its problems, prompting the free initiative of each student as well as welcoming and without prejudice to any initiative.

To be a citizen and a civilized person means to assess the man as a human being, and as such he has the right of active citizen, considering life from humane and vital viewpoint. "The tendency of citizens to be active with the problems of the community is the basis of forming expressions of participation. In a democratic system, this trend relates to the rights and responsibilities of the individual in society, with the ideals of political community and civil society "(Shakaj 2011 p.111). It is important to understand how much help is offered to students from school, how cooperative are students with their representatives, or even with each other to solve problems, how they are able to take initiatives in organizing different activities?

The mission of education and school is to find ways to improve and develop active citizenship. To identify how free are students to highlight the needs and problems of the community, and the classroom where they belong. Not only that, but let them be those who propose solutions to various problems.

"The creation of the appropriate environment that promotes critical thinking, creative and realizing who gives way to dialogue, discussion and debate, and creates opportunities for participation in school and community life, far from the tendency to be locked within the shapes, schemes and template stereotypes, solid or borrowed transplanted mechanically "(Tamo 2002 p.65).

"The perfection of the applied skills is done through practice. As a researcher says, citizen participation is a hard work. Competencies are formed through experience. On the experiences of many teachers are widely discussed various ways to involve young people in an active learning of citizenship, since the community service till the conceptualization of 
school as a political system "(Institute of Curricula and Standards 2005, p.15).

Students should be characterized by active participation in classroom, school and community where they live. To be guided by their conscience to live together as worthy citizens of a consolidated, active society with democratic basis. "People, in any environment, must work together to find out what it takes to set in motion the internal process by which people learn more and more about how to do what they need to do in order to achieve what is worth to achieve' (Fullan, 2001, p.404). "Based on these general purposes, civic education aims at the preparation of future citizens, able to exercise civic responsibilities and to cope with the future challenges by taking part actively in the social life" (Tamo1999, p.5).

Today civic education is taught extensively in Europe, as in the context of formal educational system, also in the non-formal system, aiming to encourage an active and responsible citizenship in modern democracy. Active citizenship is not a particular status that requires certain skills and competencies. It has to do with the ability of each citizen to defend his rights and exercise responsibilities in the development of public policies in function of common goods. Every society believes and hopes that her children become capable citizens and responsible to give their contribution to the growth of the welfare of the community where they live.

The duty of school is the awareness of students in solving the problems they face. "Civic education deals with the preparation of young people for a well informed participation, active and responsible in democracy based on respect of the universal human rights, equality for all, justice and pluralism "(Shakaj 2011 p.119).

In the study "Civic education in school and outside" among others is emphasized this fact: "This formation can not be classified as full and effective when it closes within the verbal sphere of activity, when abilities and communication skills with others and those of participation in social life leave much to be desired, when students are asked for the reproduction of information and they reproduce it, speak and write beautifully about the importance of the principles, rules and laws, but the requirements for their application are low. "(Como ,Tamo, Karaj 2002 p. 50-51).

\section{The Material and Method}

The essential aim of this study is directly related to that how active are students for issues and various problems in school and community. This study was realized to know and understand the role that carries the organizational and collaborative spirit in our schools. Also have to be viewed how present is the spirit of active citizenship at school, how educated are students with the skills and habits of a collaborative work like active citizens of a democratic society.

The study is based on quantitative and qualitative data obtained from the experience of teachers and students in some schools in the district of Elbasan. The main method was that of the survey through questionnaires realized with students as well as interviews realized with teachers and pupils of the schools included in the study. This information was processed and were issued conclusions, which were the product of a concrete analysis.

In this study were answered such questions as: How active are students in the meetings and decisions taken in school? Do students take initiatives for the organization of various activities and events in school and community? How much help is offered to students from the school directory? How much do teachers exceed the barriers between theory and practice?

\section{Results and Discussion}

Formation for citizenship in schools has been revised with the aim of including many concepts in the content of civic education curriculum. They are relevant to meet the changing needs and challenges for the future of the country. Civic education curriculum is projected to give greater emphasis to the responsible citizenship, to increase the feeling of engagement in the community, in order to respond to the growing of globalization, in a rapidly changing world . Alternative texts of social education from grades 6-9, create all the spaces and opportunities for students to demonstrate actions that reflect active citizenship and community involvement. This involvement is $89 \%$ in sixth grade textbooks, $90 \%$ in seventh grade textbooks, $90 \%$ in eighth grade textbooks and $88 \%$ in ninth grade textbooks.

Therefore the main role belongs to the teachers to respond to the needs of society, preparing students for active participation, creative and responsible. There is a contradiction between the advanced level programs and alternative texts on one hand, and insufficient level of teachers to realize them on the other hand. Teachers should work maximally with students to enable them to organize various activities, such as for teaching purposes and for humane purposes too. They must be aware of the contribution that they must give in school. Suggestions are the motto that should be used by teachers and never judgments. This study was realized in some 8-th and 9-th classes of 9-year schools "Ali Agjahu", 
"Jorgji Dilo" and "Abdyl Paralloi" of Elbasani district.

\subsection{Participation in the class meetings and the discussion in them}

Students say that they participate regularly in meetings organized in their classrooms. When it comes the word about discussions and expression of opinions in class meetings, the answers are different. In 9-year school "Ali Agjahu" 90\% of students say that they discuss and give their opinion about the problems that arise as a class, while $10 \%$ say that they are indifferent and do not express their opinion in these meetings. In 9-year school "Jorgji Dilo " and" Abdyl Paralloi " this report is such that $80 \%$ of students say that they give their opinion in meetings and $20 \%$ say that they can not discuss because their opinions are not taken into consideration.

\subsection{Raising voice for various problems in school and community.}

In 9-year school "Ali Agjahu" 60\% of students say that they raise their voice when they see that something is going wrong, while $40 \%$ say that they do not speak up because they have fear. In 9-year school "Jorgji Dilo" this ratio is 55\% say that they raise their voice and $45 \%$ do not express their opinion when it is needed. In 9-year school "Abdyl Paralloi" this report is such $58 \%$ of students said yes,so they raise their voice and $42 \%$ do not.

\subsection{The support of students by the School directory.}

In 9-year school "Ali Agjahu" 90\% of students say that they have the support of School directory in solving problems, while $10 \%$ say that they do not have the necessary support in any case. In 9-year school "Jorgji Dilo" this ratio is $80 \%$ state that they have the support of School directory and $20 \%$ say that they do not have the necessary support from the Directorate. In 9-year school "Abdyl Paralloi" this report is such that $73 \%$ of students said yes, so they have the support and $27 \%$ say that they do not have enough support. If students are organized they can break some walls that at first sight seem very thick, impassable. It is important that students do not withdraw before difficulties and have the courage to go things to the end.

\subsection{Organizing activities by students.}

Students asked about the activities organized in their school, say that they participate and follow with pleasure these activities, particularly those organized by their teachers or the school directory. When asked whether there are activities organized on their own initiative they are expressed as follows: in 9-year school "Ali Agjahu" $90 \%$ of the students said yes, while $10 \%$ say that they have not taken initiatives on their own. In 9-year school "Jorgji Dilo" this ratio is $75 \%$ say yes and $25 \%$ say no. In 9-year school "Abdyl Paralloi" this ratio is $80 \%$ of the students said yes, they have taken initiatives and $20 \%$ said they have not taken such initiatives on their own.
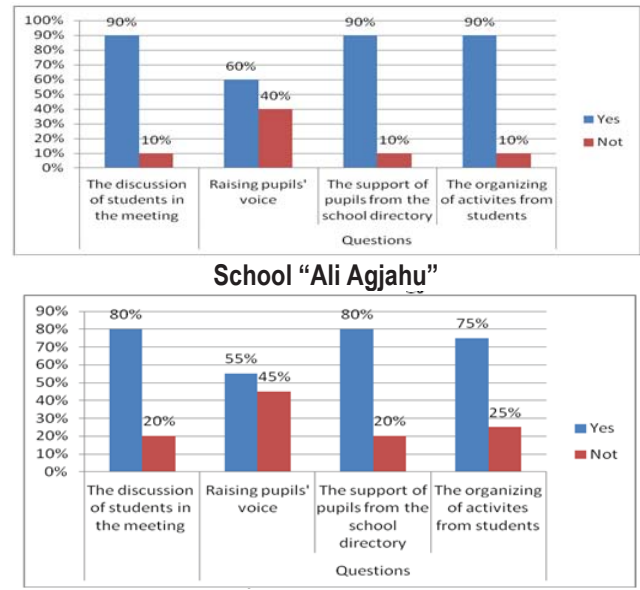

School "Jorgji Dilo" 


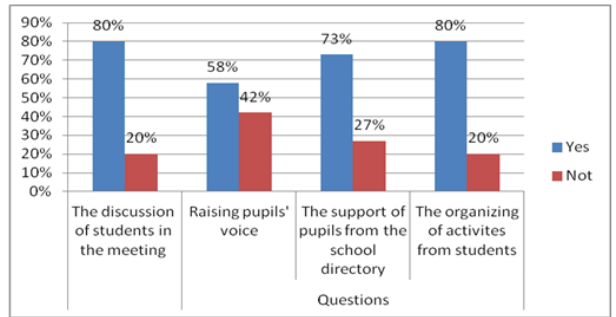

School "Abdyl Paralloi"

The findings in this study showed that:

- Students participate in meetings which are organized in the classroom, but the discussion about the problems that concern students, leaves much to be desired. There is noted a certain indifference or sign of disbelief by students in solving various problems that they come across.

- Students participate in activities which are organized in the classroom and school, but in most cases they participate as decoration and do not take such initiatives themselves.

- There are young people who are willing to contribute in their community, but do not have the opportunities and the necessary information to realize their ideas.

- Teachers must work harder to overcome the barriers between theory and practice, and they are guided in their work by the motto: "Let's learn by participating."

- The curriculum reflects a fair balance between knowledge in texts, expressions of education and the formation with active citizenship, but there is left a little space to the formation of the expressions related to communication with others and the participation in community life.

- There exists the advanced level of programs and the use of alternative texts, but should be worked harder in the direction of increasing the level of teachers, as it is not in the standards that time requires to realize qualitative lesson plans.

- There is lack of teacher trainings for the preparation of active citizens of tomorrow,that respect the opinion of others, that confront with the others, in order to tolerate and take decisions, that discuss and debate defining the attitude in complex situations.

\section{Conclusions}

Abilities and intellectual skills have their importance for students' civic formation.

Schools should be characterized by open and diverse relationships with the community, because the preparation of individuals for self-determination, participation and solidarity in projects and organizations outside of lesson and school and provides a wide range of theoretical and practical knowledge.

Free activities organized by students and school should be linked to community life. Students must participate actively in solving various problems, creating opportunities to exercise their rights and responsibilities where they live. Young people should be encouraged for decision-making in their school or community, for the role that should play in society and the opportunities to make changes in the improvement and development of active citizenship.

\section{References}

Fullan, M. New understanding of change in education, the Center for Democratic Education (CDE) Tirana, Edualba, 2001. Institute of Curricula and Standards, Citizenship in school in XXI century, Tirana 2005.

Law on Pre-university Educational system, Tirana 1995.

Shakaj, V., Didactics of Education for Democratic Citizenship, Tirane, Julvin-2, 2011.

Tamo, A. , Como, B. , Karaj, Th. Civic education in school and outside, CRS, Tirana, 2002.

Tamo, A., Education for Democratic Citizenship in the Elementary School, Tirana, Pegi 1999. 